\title{
Rorty as a Legitimate Member of the Pragmatist Family
}

\section{Giovanni Maddalena}

\section{(2) OpenEdition \\ 12 Journals}

Electronic version

URL: http://journals.openedition.org/ejpap/1848

DOI: 10.4000/ejpap.1848

ISSN: 2036-4091

\section{Publisher}

Associazione Pragma

\section{Electronic reference}

Giovanni Maddalena, "Rorty as a Legitimate Member of the Pragmatist Family », European Journal of Pragmatism and American Philosophy [Online], XII-1 | 2020, Online since 16 June 2020, connection on 26 June 2020. URL : http://journals.openedition.org/ejpap/1848; DOI : https://doi.org/10.4000/ejpap 1848

This text was automatically generated on 26 June 2020 .

\section{$(\mathbb{D} \Theta \Theta$}

Author retains copyright and grants the European Journal of Pragmatism and American Philosophy right of first publication with the work simultaneously licensed under a Creative Commons AttributionNonCommercial-NoDerivatives 4.0 International License. 


\title{
Rorty as a Legitimate Member of the Pragmatist Family
}

\author{
Giovanni Maddalena
}

1 Important scholars of classic pragmatism deny any relationship between Rorty and the roots of pragmatism. Rorty is particularly at odds with the Peircean architecture of thought, at least at a first glance. Peirce was talking about the pragmatist way to get at truth through scientific research conducted in the long run. He was defending a strong sense of the value of communities and social experience, a very profound and original approach to mathematics, phenomenology, semiotics, metaphysics. Rorty seems simply the opposite. He used the name of pragmatism for very different attitudes towards truth, research, science and, obviously, reality. Even worse, he seemed to highlight a sort of individualism and the abandonment of Philosophy (with capitalized P). Finally, his parasitic view of philosophy as cultural criticism does not respect the passion for solving philosophical problems which was at the heart of pragmatism understood in a Peircean way. On moral ground, then, he advocates ideas that seem to prevent human beings from having a good foundation to say that Hitler or Stalin were wrong. While this is a caricatured portrait of Rorty, he nevertheless often voluntarily played the role of the radical adversary of any tradition in philosophy, including classic pragmatism, and any usual description or definition of the classic terms of philosophy.

2 In the series of interviews with contemporary philosophers associated with the pragmatist tradition entitled Let me Tell you a Story: Heroes and Events of Pragmatism, published in this review, we collected some interesting opinions about Rorty's role within the pragmatist family. Despite the many philosophical controversies raised by the "outrageous Rorty," in Bernstein's description of the provocative side of his colleague and friend (Maddalena, Frega \& Bernstein 2014: 7), many of authors interviewed in the series acknowledge Rorty's contribution to the pragmatist debate. Bernstein rejects the idea of a fixed canon of American philosophy precisely because it would leave out important figures like Rorty (ibid.: 4). While criticizing Rorty's propensity to interpret classical texts by Dewey and James in an excessively free manner, Putnam cannot fail to recognize that he managed to get people - even Putnam 
himself - to read pragmatism (Bella, Boncompagni \& Putnam 2015: 7). Moreover, Larry Hickman insists on the key role Rorty's 1979 presidential address to the American Philosophical Association played in changing the feeling that pragmatism was being marginalized by the prevalence of analytic philosophy (Bella, Santarelli \& Hickman 2015: 7). Already after the publication of Philosophy and the Mirror of Nature, many pragmatist scholars and philosophers sympathetic to pragmatism criticized Rorty's misusing of Dewey (cf. Bernstein \& Voparil 2010: 2). However, Susan Haack's criticism of Rorty's "vulgar" pragmatism is perhaps the harshest (Haack 1995). As is well known, Haack also recently maintained that Rorty confusedly misinterpreted many pragmatist issues, first of all that of foundationalism, and that he has reconnected himself to this philosophical tradition for purely intellectual marketing reasons (Yong \& Haack 2010: 15). Certainly, Haack is technically right, if you look at the outcome of Rorty's statements. Her arguments are keen and compelling. They seem to close the debate definitively.

However, this is not the only possible way of reading Rorty. Rosa Maria Calcaterra (2019), for example, reads Rorty as a complete representative of the pragmatist spirit and she sees a profound continuity between Rorty and classic pragmatists, including many sides of Peirce's account of knowledge. This difference in evaluation is due to focusing more on Rorty's philosophical needs - namely, on the general direction undercurrent of his thought - than on the propositions he maintains: "for it is the belief men betray and not that which they parade that has to be studied" (EP2: 349). Assuming a sympathetic attitude toward Rorty's view, Calcaterra suggests that Rorty's move from experience to language heralds a "new pragmatic anthropology" that emphasizes the link between normativity and linguistic practices (cf. Calcaterra 2019: 111ff). While as for Peirce's philosophy, deliberately overlooked by Rorty, she detects interesting "family resemblances" between Rorty's contingentism and Peirce's "dialectic of chance and regularity." More specifically Calcaterra wonders whether Rorty's contingentism cannot be read as a postmodern translation of classical pragmatist metaphysics and, in any case, she finds that "Peirce's tychism might provide an interesting theoretical integration of the issues at stake in the ethical claim accompanying Rorty's critique of the absolutistic implication of modern metaphysics" (Calcaterra 2019: 123). This interesting suggestion, a profound study of Peirce's mature philosophy, and an awareness of the history of the effects of pragmatism suggest that a re-examination of the problem is worthwhile, even if the outcome of this research were to differ from both Haack's and Calcaterra's findings.

4 In this paper, I will focus on the results of this further deepening of Rorty's philosophy, which I hope can account for the fact that he can give some help also to those who do not agree with some of the aims or the means he suggests. In particular, I will focus on the project he wanted to foster as he stated it in the provocative introductions to his books from Philosophy and the Mirror of Nature onwards. From this project, I extrapolate three interesting items that compel to accept the hard truth that Rorty was a legitimate member of the pragmatist family and that he shared with classic pragmatists much more than scholars usually think and, possibly, something different from what he thought to share with them. The three topics that I will follow here are: 1) antiKantism; 2) a peculiar kind of holism; 3) the attitude toward culture and politics. 


\section{Rorty's Anti-Kantism}

5 The first aspect I want to underline is that Rorty understood better than anyone else that the fight against Kant's philosophy is crucial to pragmatism considered as a whole. As Calcaterra shows in her book, Rorty knew Peirce and classic pragmatism even if his reading was always peculiar (Calcaterra 2019: $2 \mathrm{ff}$ ). Through this reading, misleading as it could have been, he got a profound sense of pragmatism. Rorty understood that pragmatism had to be anti-Kantian or not to be at all. Notwithstanding Peirce's youthful love for the German master, Peirce himself grew anti-Kantian as much as his work was going on. He completely abandoned Kant in the late phase of his thought (Maddalena 2019). Rorty could not have read it because it was not available at the time he was studying but Peirce harshly criticized Kant's distinction of noumenon and phenomenon, labeling it as nominalism, attacked the idea of the transcendental deduction of the Self, proposed a radical alternative to the separation of fields of inquiry (theoretical, moral, aesthetical) that emerged from Kant's critical project (Maddalena 2015: 10-29). We can obviously discuss about the accuracy of such a reading of Kant's work, but this was the one that Peirce gave. Classic pragmatists followed more or less the same path of critiques and Rorty took his anti-Kantian conviction from James and Dewey, not having access in his youth to Peirce's late manuscripts.

6 How did Rorty translate the classic pragmatists' concerns about Kant? It is the famous incipit of Philosophy and the Mirror of Nature:

To know is to represent accurately what is outside the mind; so to understand the possibility and nature of knowledge is to understand the way in which the mind is able to construct such representations. Philosophy's central concern is to be a general theory of representation, a theory which will divide culture up into the areas which represent reality well, those which represent it less well, and those which do not represent it at all (despite their pretense of doing so). (PMN: 3)

7 This Kantian model arrived at a dead end in the second part of twentieth century, showing a kind of philosophy that cannot address problems felt by the people and that is uselessly involved in problems that have no escape and no fruits to bear. Rorty ascribes the fault of this kind of picture of philosophy to the notorious trio DescartesLocke-Kant and labels it as "Foundationalism" (PMN: 3). However, Kant is the symbolic summary of them all and the reference for everything else that followed in philosophy, including analytic philosophy that Rorty acutely sees as "one more variant of Kantian philosophy" (PMN: 8). Rorty's assault to this tradition is in the name of antifoundationalism. However, he mistakes this tradition for almost the entire tradition of philosophy and, as Haack suggests, he confuses different types of foundationalism. I think we should be a little more precise than him and that there are other ways out from this situation of contemporary philosophy, but the relevance of the denounce and the idea of picking up anti-Kantism as a basic characteristic of pragmatism is as crucial as genial.

What does it mean to be more precise than Rorty on this point? As for the claim of antifoundationalism, as I argued in my book The Philosophy of Gesture (2015), the real problem with the Kantian picture of philosophy, a good representative of the modern tradition of philosophy, is that foundation according to Kant has to be necessary and a priori, whether this a priori happens in the mind, in the physical, or in the metaphysical world. The image of necessity that modern epistemology presented is always tied to reality and inquiries in which there are parts and wholes, whether we 
can build up wholes by adding parts or we can single out parts by analyzing wholes. No wonder that Kant gave us this maneuver of composition and decomposition as a description of necessary analytic reasoning and tried problematically to find out a way to depict synthetic a priori judgements according to the same characteristics. Susan Haack correctly says that Rorty would have won his anti-Kantian battle, if only he had demonstrated the impossibility of synthetic a priori judgments (Haack 1995: 131-2). The account of synthetic a priori judgments in terms of analyticity is at the core of Robert Hanna's (2001) attempt to defend Kant's position. However, Hanna's work shows that at the end Rorty was right to reduce Kant's view of reasoning, including a priori synthetic judgments, to analysis. This move implies also that the Kantian form of knowledge ends up in the famous conception of representation as mirror. In fact, Hanna argues that synthetic a priori judgments are grounded in aesthetic intuition, which, in turn, relies on a conception of unique space and time. In this way, the certainty of synthetic a priori judgments depends on segmenting the whole of space and time into parts. The part-whole scheme that presides over analytic judgments is then at the heart of any judgment discerned by Kant. The representation that Rorty attacks is the one that gives us back reality as parts or wholes, ready to be analyzed. Somehow, he acknowledges that the issue is about a priori necessity and not about any foundation and any representation. He even refers explicitly to this preconceptual way to look at necessity:

In the visions of the epistemologist, this incoherent notion takes the form of seeing the attainment of truth as a matter of necessity, either the "logical" necessity of the transcendentalist or the "physical" necessity of the evolutionary "naturalizing" epistemologist. (PMN: 376)

8 Rorty is right in saying that pragmatism refuses this image, but, surprisingly for him, Peirce here would be the right philosopher in order to tackle this issue, even though he speaks about signs and representation all the time. Peirce does not think of representation as a mirror. According to him, representation is an action, a transformation of reality, which is part of reality itself. His metaphysical realism amounts to this view of continuity between any modality of experience that he inquired in every field of research. James, who paradoxically defined himself a nominalist but who averted Kant's philosophy with all his strengths, approved the same version of knowledge as continuity (cf. James 1907; Maddalena 2015; Bella 2019). The second Wittgenstein to whom Rorty often refers is not far away from Peirce's path, as Colapietro showed in his article "Allowing Our Practices to Speak for Themselves" (2011). If Rorty had the care and the time to unravel the pragmatist concept of continuity, he would have seen that it casts a light on a kind of foundation that, as in mathematics, it happens while inquiry and life are going on. I call it an a posteriori foundation and I did not develop it except for what has to deal with epistemology. I think it is an idea that respects Rorty's refusal of foundationalism and his claims that the refusal of a priori, namely, of Kantian foundationalism, does not mean to become irrational and that knowledge has a lot to do with history. A deep point of disagreement with Rorty remains, since I see Rorty's historicism too stiff and preconceptual; paradoxically, historicism becomes an a priori in itself forbidding to accept different kinds of epistemology and metaphysics. I would recommend Rorty not to become ideological, namely, fixed in preconceived ideas, on this issue for the same reasons he opposes Kant, but certainly the history and development of continuity are important also for an a posteriori foundationalism, above all for understanding what resists to time and what does not. 
9 As for the tradition of philosophy, Rorty accuses modernity as a whole while he accuses Kantism but he often expands his allegations against this kind of foundationalism to the entire history of philosophy. I would be more cautious. Our modern lenses may mislead us. Peirce himself explained that, as far as reasoning is concerned, the idea of reasoning as a chain of parts is only a modern invention. He preferred the medieval version of reasoning that he described as a cable whose robustness depends upon unity among many different threads: "Its reasoning should not form a chain which is not stronger than its weakest link, but a cable whose fibres may be ever so slender, provided they are sufficiently numerous and intimately connected" (EP1: 29). Also on a metaphysical level, Scotus' metaphysics and some of the Greek or Latin accounts could be read in different ways and, as Haack confirms in her same work, there are several forms of foundationalism (Haack 1995). Therefore, I would probably prefer to say that the path of modernity has taken this a priori, foundationalist-mentalist direction that Rorty described and can be reversed, if we want to.

\section{Hang Together}

10 The second aspect of Rorty's philosophy that I want to underline here is the "synthetic drive" of pragmatism. With this expression I mean the tendency of the entire classic movement to go beyond the analytic frame that encompasses the epistemology of modern philosophy from Kant on. As we have mentioned, Kant's description of synthesis is built upon analyticity. In the past few centuries, analysis has become almost a synonymous of knowledge. Sometimes also classic pragmatists, especially Peirce, indulged in this attitude to think that knowledge is about "very simple, clearly and distinctly knowable things" (PMN: 357 ) and that the task of philosophy is to arrive at them or to describe them or to do something with a composition of them. However, in their most significant writings all classic pragmatists were aware that knowledge and language were "tools" (CP: xix) for transforming reality, while the tool itself is continuous to that reality and changes with it.

11 Synthesis is an act that modifies reality and, therefore, is part of a transition among modalities of reality. My way of summing up the legacy of classic pragmatists on this point is to say that synthesis is a "recognition of identity through changes" and its tool is called "gesture," an action with a beginning and an end that carries on a meaning (Maddalena 2015: 68ff). We know by doing but doing has a mathematical and semiotic structure. As Peirce said, the reasoning that brings to the synthetic result $A=B$ is more original than the $\mathrm{A}=\mathrm{A}$, flat, analytic identity, which is only a derivative case. Reasoning synthetically through changes happens by understanding change as a mathematical continuum (Zalamea 2012; Vargas 2015) and by some actions that happen within this continuum of changes. Real synthetic reasoning happens through actions that have a precise structure. I drew this structure from Peirce, who built up an iconic logic called Existential Graphs on this ground. Peirce was proud of the Graphs because they were a "proof" of pragmatism, namely they showed that meaning coincides with the development of all the effects of an idea ("all conceivable effects," Peirce used to say) (Zalamea-Nubiola 2011). I extended Peirce's insights with the logic of existential graphs to any action that could bring a meaning using the same phenomenological and semiotic structures. I call "complete gestures" those habits of action that carry on a meaning, namely, that synthetize our experience that happens in continuous change 
making us understand something new. Complete gestures have a phenomenological and semiotic structure in which all categories (firstness, secondness, and thirdness) and kinds of signs (icons, indices, and symbols) are involved in a dense way. Public and private rites, scientific experiments, performing arts can be good examples of complete gestures.

Rorty could not go that far and he did not want to, aware that a new definition of synthesis will open up a new epistemology, while he wants to abandon any epistemology. However, let us stop and think for a moment to what he says.

The Deweyan notion of language as tool rather than picture is right as far as it goes. But we must be careful not to phrase this analogy so as to suggest that one can separate the tool, Language, from its users and inquire as to its "adequacy" to achieve our purposes. The latter suggestion presupposes that there is some way of breaking out of language in order to compare it with something else. But there is no way to think about either the world or our purposes except by using our language. (CP: xviii-xix)

He recalls this Deweyan attitude to describe language as a tool as far as we do not separate the "tool, Language, from its users and inquire as to its 'adequacy' to achieve our purposes" (CP: xix). Then, he reminds us that "there is no pragmatic difference, no difference that makes a difference, between 'it works because it is true' and 'it is true because it works"' (CP: xxix) and that he wants to avoid the philosophical tendency "of isolating the essence of Truth," a trick that did not produce any fruit. In Philosophy and the Mirror of Nature he already recalled that the problem with the Platonic frame of philosophy is that epistemic criteria should be eternal and, at the same time, he could not find them but in our "current practice" (PMN: 374). Finally, in the introduction to Consequences of Pragmatism, Rorty describes philosophy as that kind of conversation that hopes to look at anything in a way that makes it "hang together with everything else" (CP: xxxix). If one adds these statements to the long attack to any form of intuitionism that Rorty carries out in the very same introduction a classic pragmatist drive for synthetic knowledge emerges. Here synthesis is not the reverse of analysis. It is the way in which we make things hang together. Rather, it is the habit of action, the practice of knowledge in which we are immersed and with which we are endowed. Even more significantly, this practice wants to unite working and truth, "the nature of truth and the test of truth" (CP: xxix). From Peirce's existential graphs to Dewey's logic and Mead's conversation by gestures, pragmatists have pointed out that knowledge is a kind of action that mixes up different levels of phenomena and signs or, seen in another light, that truth "happens to an idea" (James 1907: 97), namely, we find that things are usefully hanging together and we participate socially to the way of arranging them. Knowledge has to get out of the mentalism and rationalism, and it has to work. This is the a posteriori foundation that we can have. Remaining in a jargon more familiar to Rorty, here you can catch a glimpse of Quine's holism. In this holism, that Rorty wants to be no epistemology - but he really means the Kantian-epistemology one may find the legacy of that synthetic drive that sometimes remained unconscious and undetected even to classic pragmatists themselves.

Unfortunately, at least in my view, also on epistemology Rorty sticks to a preconceptual refusal. In this case he sticks to a linguistic level of experience and to his naturalism/ historicism for which culture can have "no goals outside itself" (PMN: 362), even though the story of this refusal of the non-linguistic experience might be more complicated or nuanced than that, as Rosa Maria Calcaterra explains in a very 
sophisticated and challenging chapter of her book (Calcaterra 2019: 22ff). In general, the result of this refusal to trespass the threshold of language seems to forbid Rorty to give a different chance to epistemology of any form. To me, this is an unfortunate outcome of a very promising attack to rationalism. It looks like a preconceptual way to block the road of inquiry: why should we forbid that everything might happen to hang together? Why should we forbid to look for a different epistemology or a different metaphysics? ${ }^{1}$

\section{Culture and Politics} tields of inquiry as con critiques. Rorty seems to run on the same path. One can always argue that Kant wanted the three Critiques to be read together (Baggio 2019) but the history of effects is that professionalized philosophy, understood as a sort of updating of Kant's project, divides sectors of inquiry as if they were different fields of inquiry. In Italy, only to make an example, not happy enough with Kantian distinctions, we have six academic disciplines within the field of philosophy (theoretical philosophy, moral philosophy, philosophy of science, aesthetics, philosophy of language, history of philosophy). The crucial step in Rorty's strategy for unifying disciplines is to consider science as a kind of conversation exactly as any other discipline. The point is to find a conversation that changes our self-description, and there is no difference between science and any other field at this level.

To say that we have changed ourselves by internalizing new self-description (using terms like "bourgeois intellectual" or "self-destructive" or "self-deceiving") is true enough. But this is no more startling than the fact that men changed the data of botany by hybridization, which was in turn made possible by botanical theory, or that they changed their own lives by inventing bombs and vaccines. Meditation on the possibility of such changes, like reading science-fiction does help us to overcome the self-confidence of "philosophical realism." (PMN: 386)

This unification between science and any other inquiry brings Rorty to a philosophy that continues the conversation "in terms of the books one reads and discusses, rather than in terms of the problems one wishes to solve" (PMN: 394). Rorty's theoretical move becomes even more precise when he talks of blurring the border between poetry, understood as the edifying, creative side of human conversation and philosophy, 
understood as a scientific enterprise of description or exact representation of the world. We saw that the idea of unifying representation and action is at the heart of the synthetic drive of classic pragmatism. We also mentioned how the same drive emerges from time to time in Rorty's project. The outcome of the synthetic drive is that the goal of philosophy is transformative of reality, and therefore it is also political. As in the previous general case, Rorty takes possibly the opposite way in respect to classic pragmatists. They wanted poetry, arts, politics, and any meaningful action become a kind of inquiry, namely, a kind of philosophy, even though they did not understand philosophy in a "scientistic" way, with that kind of limited realism that Russell or positivists were defending at the same time. For classic pragmatists, everything, including science-fiction and art, is a problem to solve in a scientific way. Any field is connected to any other because any human enterprise is an inquiry, not a conversation. ${ }^{2}$ Peirce, as usual, systematized this intertwining among disciplines in a strict way by describing a stair of disciplines in which the highest gives principles to any lower and receives contents by any lower (EP2: 258-62). Peirce wanted metaphysics to rely for principles upon logic, logic upon ethics, ethics upon aesthetics, aesthetics upon phenomenology and phenomenology upon mathematics. The other way around worked for contents. However, if you go to the bottom of this image, the idea is really that all experiences hang together and that inquiry is our way to move within experience and to transform it. Unlike classical pragmatists, Rorty wants any philosophy, science, art, and politics to become transformative as poetry is. He thinks that any form of Philosophy (capitalized) be somehow scientistic. However, again, he runs the same path of conceiving philosophy as a transformative activity that makes things work together or hang together. This working is the only prove and condition of what we call "truth." Consequently, he understands that philosophy must be open to a political commitment. Once again, the difference between classical pragmatists' "inquiry into experience" and Rorty's "conversation" is remarkable, but I am arguing that it is worth noticing how Rorty does not see differences between disciplines and fields, a typical pragmatist move that treats aesthetic, ethical, social, and political issues as belonging to philosophy intrinsically.

\section{Conclusion}

19 Summing up, Rorty was not a preposterous exploiter of the pragmatist mark. He really belongs to the tradition of pragmatism, sharing with it many important characteristics. Here we focused on anti-Kantism, synthetic drive of knowledge, anti-separatism of sciences and disciplines. In one word, we can say that he underlined the anti-rationalist side of pragmatism. Then, he gave his solution to the impasse of rationalism and his solution is quite at odd with classic pragmatism, often leaning towards the postmodernism that flourished in Europe at his time. In my opinion this different outcome is due to some preconceptual claim about historicism, naturalism, linguistic borders of experience. He could not imagine a different form of representation, synthetic reasoning, metaphysics. Since he could not, he declared it impossible. This impossibility leads him to the aspects of his philosophy that I noticed at first and that seemed anti-pragmatist: the refusal of any kind of foundation, the rejection of any epistemology, the separation between private and public (maybe the worse aspect for a classic pragmatist). But, as I said, this surface has a very pragmatist root that has to be faced. Even those who, like me, think that a philosophical project different from the 
one of modernity is possible should pay attention to Rorty's powerful attack to rationalism that indicates the failure of some strategies they cannot repeat after Rorty.

\section{BIBLIOGRAPHY}

BAGGIO Guido, (2019), "Sense, Sign's Sense, and Gesture. For a Quasi-Transcendental Semiotics," in H. Rydenfelt \& S. Pihlström (eds.), Kant and Pragmatism, Nordic Studies in Pragmatism 4, Helsinki, Nordic Pragmatism Network, 77-97.

BARRENA Sara, (2014), "El Sistema de Charles S. Peirce: conexiones clásicas y modernas de la estética peirceana," Cuadernos de Sistemática Peirceana, 1, 7-36.

BELLA Michela, (2019), Ontology after Philosophical Psychology. The Continuity of Consciousness in William James's Philosophy of Mind, American Philosophy Series, Lanham, Lexington Books.

BELla Michela, Boncompagni Anna \& Hilary PUTNAM, (2015), "Interview with Hilary Putnam," European Journal of Pragmatism and American Philosophy [Online], VII-1, 2015.

[journals.openedition.org/ejpap/357].

BelLA Michela, SANTARELli Matteo \& Larry A. HICKMAN, (2015), "Interview with Larry A. Hickman," European Journal of Pragmatism and American Philosophy [Online], VII-2, 2015.

[journals.openedition.org/ejpap/420].

BERNSTEIN Richard J. \& Christopher J. VOPARIL (eds.), (2010), The Rorty Reader, Wiley-Blackwell.

CALCATERRA Rosa Maria, (2019), Contingency and Normativity. The Challenges of Richard Rorty, Leiden, Boston, Brill-Rodopi.

COLAPIETRO Vincent, (2011), "Allowing Our Practices to Speak for Themselves: Wittgenstein, Peirce, and Their Intersecting Lineages," in R. M. Calcaterra (ed.), New Perspectives on Pragmatism and Analytic Philosophy, Amsterdam and New York, Brill-Rodopi, 1-20.

GUARDIANO Nicholas, (2014), "Peirce's Cosmology as Metaphysical Ground for an Aesthetic

Transcendentalism," Cuadernos de Sistemática Peirceana, 1, 51-78.

HAACK Susan, (1995), "Vulgar Pragmatism: An Unedifying Prospect," in Herman J. Saatkamp Jr. (ed.), Rorty \& Pragmatism: The Philosopher Responds to his Critics, Nashville and London, Vanderbilt University Press, 126-47.

HANNA Robert, (2001), Kant and the Foundations of Analytic Philosophy, New York, Oxford University Press/Clarendon Press Publication.

JAMES William, (1975 [1907]), Pragmatism, edited by Fredson Bowers \& Ignas K. Skrupskelis, introduction by H. S. Thayer, Cambridge, MA and London, Harvard University Press.

MADDALENA Giovanni, (2015), The Philosophy of Gesture. Completing Pragmatists' Incomplete Revolution, Montreal \& Kingston, London, Chicago, McGill-Queen's University Press.

MADDALENA Giovanni, (2019), “Anti-Kantianism as a Necessary Characteristic of Pragmatism," in K. P. Skowroński \& S. Pihlström (eds.), Pragmatist Kant. Pragmatism, Kant, and Kantianism in the Twenty-first Century, Helsinki, Nordic Pragmatism Network, 43-59. 
MADDALENA Giovanni, FREGA Roberto \& Richard J. BERNSTEIN, (2014), “Interview with Richard J.

Bernstein," European Journal of Pragmatism and American Philosophy [Online], VI-1, 2014.

[journals.openedition.org/ejpap/517].

MAYORga Rosa, (2014), “The Fairy and the Aleph: On Peirce's Ethetics," Cuadernos de Sistemática

Peirceana, 1, 79-102.

PEIRCE Charles Sanders, (1992), The Essential Peirce, Volume 1: Selected Philosophical Writings

(1867-1893), edited by Nathan Houser and Christian J. W. Kloesel, Indianapolis and Bloomington, Indiana University Press [EP1].

PEIRCE Charles Sanders, (1998), The Essential Peirce, Volume 2: Selected Philosophical Writings

(1893-1913), edited by The Peirce Edition Project, Bloomington, Indiana University Press [EP2].

RAMBERG Bjørn, (2008), "Rorty, Davidson, and the Future of Metaphysics in America," in Cheryl

Misak (ed.), The Oxford Handbook of American Philosophy, New York, Oxford University Press, 430-48.

RORTY Richard, (1979), Philosophy and the Mirror of Nature, Princeton, New Jersey, Princeton University Press [PMN].

RORTY Richard, (1982), Consequences of Pragmatism (Essays, 1972-1980), Minneapolis, University of Minnesota Press [CP].

RORTY Richard, (2007), Philosophy as Cultural Politics. Philosophical Papers, Vol. 4, Cambridge, Cambridge University Press [PCP].

VARGAS Francisco, (2015), "Modelos y variaciones sobre las ideas peirceanas del continuo," Cuadernos de sistematica peirceana, 7/2015, 139-56.

YONG Sun \& Susan HAACK, (2010), "Pragmatism, Then and Now: Sun Yong Interviews Susan Haack," Pragmatism Today [Online], Volume 1, Issue 2, 2010. [pragmatismtoday.eu/winter2010/ Pragmatism_Today_Volume1_Issue2_Winter2010.pdf].

ZALAMEA Fernando, (2012), Synthetic Philosophy of Contemporary Mathematics, New York, Urbanomics.

ZALAMEA Fernando \& Jaime NUBIOLA, (2011), "Existential Graphs and Proofs of Pragmatism,"

Semiotica, 186, 412-39.

\section{NOTES}

1. According to Ramberg, Rorty's engagement with Davidson's systematic philosophy can be read as potentiation of Rorty's anti-metaphysical pragmatist project to "let philosophy be cultural politics" (Ramberg 2008: 446).

2. My contention that Rorty's synthetic drive follows the opposite direction from the classical pragmatists (going not from poetry to inquiry but vice-versa) is not a way to say that Rorty does not share a lot with them especially on the transformative role of philosophy - particularly with Dewey. Instead, it is a way to underline their affinity as "anti-scientists" while also taking into account the incidence of hermeneutics in Rorty's philosophy. The transformative pragmatist stance is evident also in Rorty's preface to Philosophy as Cultural Politics (2007): “In Dewey's work, historicism appears as a corollary of the pragmatist maxim that what makes no difference to practice should make no difference to philosophy. 'Philosophy,' Dewey wrote, 'is not in any sense whatever a form of knowledge.' It is, instead, 'a social hope reduced to a working program of 
action, a prophecy of the future.' From Dewey's point of view, the history of philosophy is best seen as a series of efforts to modify people's sense of who they are, what matters to them, what is most important" (PCP: viii). Indeed, I think Rorty underrates the role of inquiry in his reading of Dewey. If he did not do so, he would see that the transformative stance and the role of knowledge are not opposed to one another. In any case, though, the importance of philosophy for transforming the world is a permanent characteristic of pragmatists.

\section{ABSTRACTS}

The paper will focus on Rorty's project as it emerges in the compelling introductions to his books from Philosophy and the Mirror of Nature onwards. Even disagreeing with his conclusions, some interesting items suggest that Rorty was a legitimate member of the pragmatist family and that he shared with classic pragmatists much more than a reader can see at first glance. First, Rorty understood better than anyone else that the fight against Kant's rationalism is crucial to pragmatism considered as a whole. He paralleled Kantism with the history of explaining knowledge as a mirroring representation and he wanted to get rid of it. Second, Rorty shared with classic pragmatists what I call the "synthetic drive" of philosophy, namely, the view of philosophy as the habit of action of looking at anything in a way that makes it "hang together with everything else." Third, the outcome of the synthetic drive is conceiving philosophy as a transformative activity. In all these cases, Rorty took roads at odds with classic pragmatism but he did not betray the general aim and spirit of the American movement of thought.

\section{AUTHOR}

\section{GIOVANNI MADDALENA}

Università del Molise

maddalena[at]unimol.it 